\title{
Does blood pressure reduction necessarily compromise cardiac function or renal hemodynamics? Effects of the angiotensin-converting enzyme inhibitor quinapril
}

\begin{abstract}
Clinical studies indicate that the angiotensin-converting enzyme inhibitor quinapril is an effective antihypertensive agent when administered once daily. At the end of a 4-week, double-blind crossover trial comparing quinapril and placebo, patients were admitted for a hemodynamic profile study 12 hours after taking the previous dose. A final $20 \mathrm{mg}$ dose of quinapril had no additional effect on blood pressure. This is interesting inasmuch as the plasma half-life of the active metabolite quinaprilat is approximately 2 hours and the effective accumulation half-life is approximately 3 hours. The blood pressure reduction in patients with mild hypertension receiving long-term quinapril therapy may be more closely related to prolonged angiotensin-converting enzyme inhibition or to an effect on tissue angiotensin II concentration than to the plasma half-life. This may be the case particularly for cardiac output and renal circulation, because quinapril lowers total vascular resistance without increasing cardiac output or disturbing autoregulation of renal blood flow. Reduced ventricular wall stress, improved diastolic function, and lower renal perfusion pressure may spare cardiac function and glomeruli from hypertensive vascular damage. (AM HEART J 1992;123:1433-8.)
\end{abstract}

Sverre E. Kjeldsen, MD, PhD, ${ }^{a}$ Rakesh K. Gupta, MD, ${ }^{\mathrm{b}}$ Lisa Krause, MS, ${ }^{\mathrm{b}}$

Alan B. Weder, MD, ${ }^{\mathrm{b}}$ and Stevo Julius, MD, ScD. ${ }^{\mathrm{b}}$ Oslo, Norway, and

Ann Arbor, Mich.

Currently available antihypertensive drugs lower blood pressure through widely different hemodynamic mechanisms. In general, $\beta$-blockers tend to produce chronic depression of cardiac output, particularly during exercise, ${ }^{1}$ and consequently may induce reduction of physical endurance during severe work loads. ${ }^{2-4}$ In contrast, $\alpha$-blockers, calcium-channel blockers, and angiotensin-converting enzyme (ACE) inhibitors reduce vascular resistance and maintain blood flow, ${ }^{5-11}$ but the degree of counteracting reflex tachycardia and the increase in cardiac output vary widely.

The antihypertensive effect of ACE inhibitors is likely mediated largely by withdrawal of the vaso-

From the Department of Internal Medicine, Ullevaal University Hospital, and the Division of Hypertension, Department of Internal Medicine, University of Michigan Medical Center. ${ }^{\text {b }}$

Reprint requests: Sverre E. Kjeldsen, $\mathrm{MD}, \mathrm{PhD}$, Department of Internal Medicine, Ullevaal Hospital, N-0407 Oslo 4, Norway. 4/0/32320 pressor influences of angiotensin II, ${ }^{12,13}$ although other mechanisms, such as bradykinin potentiation, have been proposed. ${ }^{14,15}$ Both angiotensin II withdrawal and bradykinin potentiation result in arteriolar dilatation and the resultant decrease in vascular resistance. Quinapril hydrochloride is an orally active, nonsulfhydryl, nonpeptide ACE inhibitor approved for the treatment of hypertension and congestive heart failure in a number of international markets. ${ }^{16}$ Clinical studies indicate that quinapril is an effective antihypertensive agent when administered once daily. ${ }^{17-19}$ This is interesting, inasmuch as the plasma half-life of the active metabolite, quinaprilat, is approximately 2 hours and the effective accumulation half-life (based on urinary excretion) is approximately 3 hours. ${ }^{20} \mathrm{We}$ investigated cardiac and renal hemodynamic effects of quinapril ${ }^{21}$ in relation to a stable blood pressure reduction of approximately 10 to $15 \mathrm{~mm} \mathrm{Hg}$ (compared with placebo) both at home and in the clinic in patients who monitored their own blood pressure, and who had estab- 
lished diastolic blood pressure at home of greater than $95 \mathrm{~mm} \mathrm{Hg}$ when untreated (i.e., no "white coal" phenomenon). Here we obtain detailed records from the daily home blood pressure and heart rate measurements of the 10 patients, and we also present individual patient changes in cardiac index and renal blood flow as well as evidence of improved diastolic function.

\section{METHODS}

Patients. Ten white men averaging $42 \pm 3$ years (range, 32 to 61 years) with uncomplicated mild to moderate essential hypertension were studied. ${ }^{21}$ After informed consent was obtained, all antihypertensive medications were discontinued for 3 weeks, and patients were included in the study if they had stable diastolic blood pressures between 95 and $115 \mathrm{~mm} \mathrm{Hg}$ at home (sitting) and in the outpatient clinic (supine) at the end of this period. One patient was stable on thyroid hormone replacement. Aside from essential hypertension, no subject had any other acute or chronic illness. All patients were nonsmokers and did not abuse alcohol or drugs. They were urged not to change their dietary or drinking habits during the study period.

Protocol. After the initial 3 weeks without antihypertensive treatment, patients were randomly assigned to a double-blind, two-period crossover trial comparing quinapril and placebo. Quinapril, $20 \mathrm{mg}$, or matching placebo was each given twice daily for 4 weeks. On the last day of each 4-week period, 12 hours after taking the next to last dose of medication, and having fasted for 12 hours (i.e., overnight), patients were admitted to the University of Michigan Clinical Research Center for 4 hours for hemodynamic profiling.

Subjects were placed at supine rest in a quiet room. Baseline blood pressure was measured in the right arm as the average of two readings by a newly calibrated mercury sphygmomanometer, and baseline heart rate was calculated from the average of 20 to 40 beats taken from the ECG tracing. After baseline blood pressure and heart rate were measured, the morning dose of medication (quinapril or placebo) was given. Thereafter, blood pressure and heart rate were measured every half hour throughout for 4 hours, and hemodynamic profiling was performed 2 to 4 hours after the last dose. The echocardiographic and Doppler procedures used in this study are described in detail elsewhere. ${ }^{22,} 23$

Plasma clearance of paraaminohippuric acid (PAH), an estimate of effective renal plasma flow, was measured at $3^{1 / 2}$ hours after the administration of the morning dose of placeho or quinapril by a steady-state infusion method. ${ }^{24,25}$ A plasma blank was first obtained, after which an intravenous priming dose of $8 \mathrm{mg} / \mathrm{kg}$ of $\mathrm{PAH}$ was administered over a 10 -minute period. $\mathrm{PAH}$ was then infused for 1 hour, from $2 \frac{1}{2}$ to $3 \frac{1 / 2}{2}$ hours after the dose of placebo or quinapril was given, at a rate calculated to achieve a target PAH plasma concentration of $0.02 \mathrm{mg} / \mathrm{ml}$. A single blood sample was drawn for measurement of $\mathrm{PAH}$ concentration at the end of the 1-hour infusion, and PAH clearance was calculated from the infusion rate and steady-state PAH concentration. ${ }^{25}$ Hematocrit level was obtained with a Coulter counter M4 30 (Coulter Electronics, Inc., Hialeah, Fla.), and renal blood flow was calculated as renal plasma flow/(1 - hematocrit). Endogenous urinary creatinine clearance was measured to estimate average glomerular filtration rate during the 24 -hour period that preceded the hemodynamic profiling. Plasma catecholamine values were obtained at the same time as the PAH plasma blank and analyzed with the radioenzymatic method of Peuler and Johnson. ${ }^{26}$

The study was approved by the Human Subject Review Committee of the University of Michigan.

Statistical analysis. The data were tested for an order of treatment effect. Because none could be found, further analyses compared the quinapril-treatment with the placebo-treatment period, regardless of the order in which they were given. Blood pressure and vascular resistance were postulated to fall; therefore differences in these variables were tested by one-tailed tests. Other differences were tested by two-tailed parametric tests for single or repeated measurements. A value of $p<0.05$ was considered the limit for statistical significance. Data are presented as means $\pm \mathrm{SE}$.

\section{RESULTS}

Blood pressure. Blood pressure was significantly lowered by treatment with quinapril compared with placebo. As shown in Fig. 1, $A$ and $B$, home blood pressures, both systolic and diastolic, averaged 10 to $15 \mathrm{~mm} \mathrm{Hg}$ lower for those receiving quinapril compared with placebo ( $p<0.001$, analysis of variance) for most of the 4-week period. However, at the beginning and end of each treatment period, differences leveled out because of the crossover design and slightly different lengths of individual treatment periods. Blood pressure recordings and differences between quinapril and placebo were of the same levels and magnitudes in the clinic as those measured by the patients at home. Also, the single dose of quinapril administered 12 hours after the last long-term drug dose had no discernible additional effect on blood pressure at the expected peak pharmacodynamic action, that is, 3 hours after the dose of quinapril.

Heart rate and plasma catecholamines. There was no significant difference in home heart rate between the quinapril and placebo treatments (Fig. 1,C). There also was not a significant difference in plasma catecholamine values between the two treatment groups: plasma norepinephrine drawn $2 \frac{1 / 2}{2}$ hours after the dose averaged $220 \pm 25$ versus $202 \pm 16 \mathrm{ng} / \mathrm{L}$ (NS) with quinapril and placebo, respectively, and plasma epinephrine was $45 \pm 5$ versus $47 \pm 10 \mathrm{ng} / \mathrm{L}$ (NS).

Cardiac function. Cardiac index was not altered by treatment with quinapril in the 10 patients (Fig. 2). Thus all the blood pressure-lowering effect of quinapril was the result of a decrease in total vascular resistance $(49 \pm 2$ versus $43 \pm 2$ arbitrary units 
Home Systolic Blood Pressure

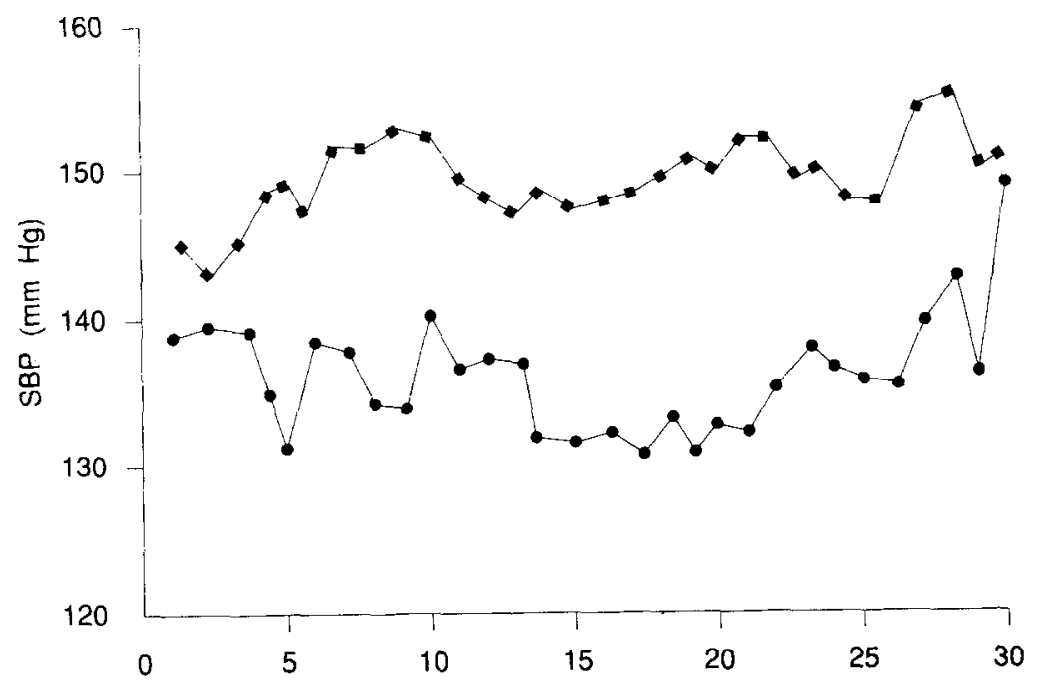

A Day of Home Blood Pressure Recording

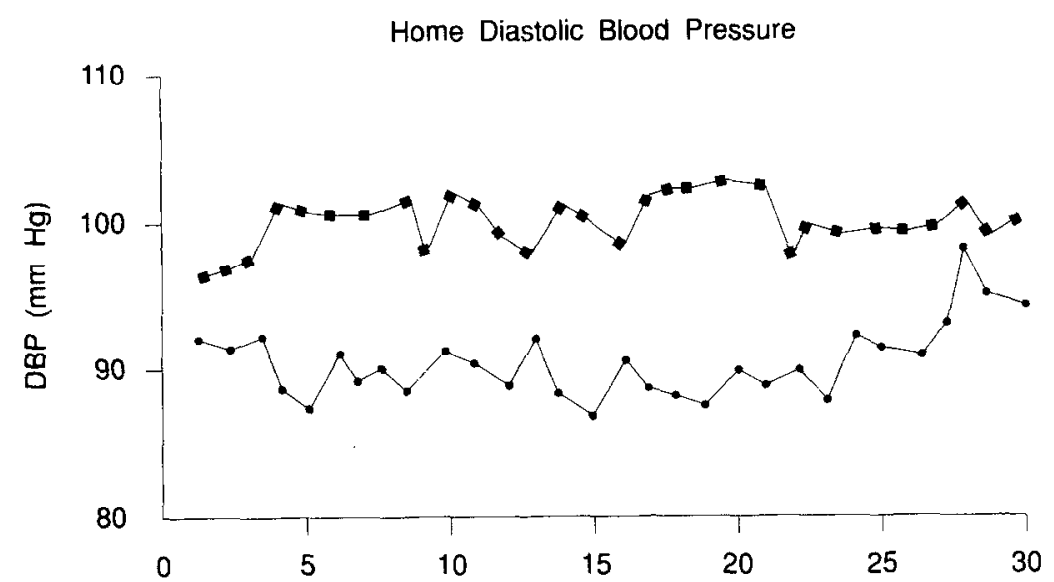

B Day of Home Blood Pressure Recording

Home Heart Rate

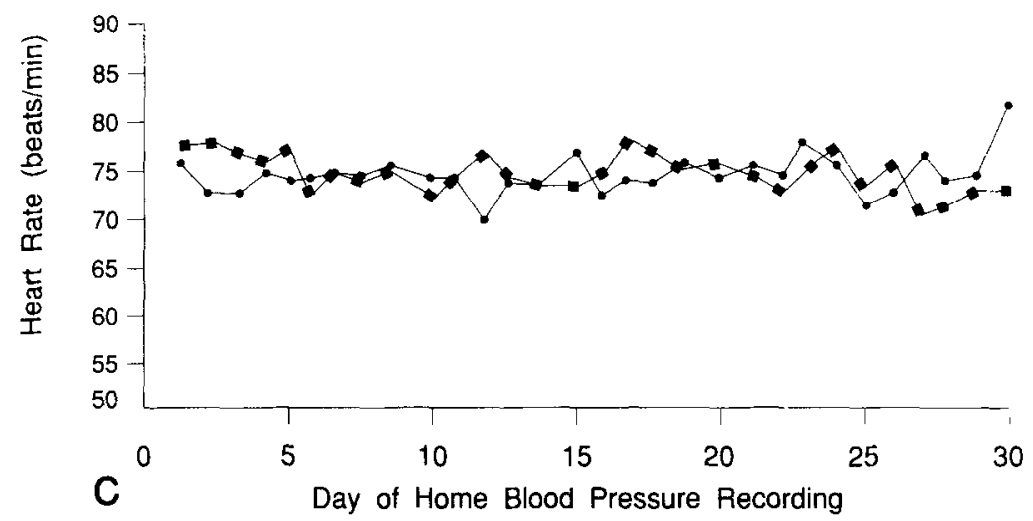

Fig. 1. Effects of quinapril (circles) and placebo (squares) on (A) home systolic blood pressure (top panel, $p<0.001$ ), (B) home diastolic blood pressure (middle panel, $p<0.001$ ), and (C) home heart rate (lower panel, NS). 


\section{Cardiac Index}

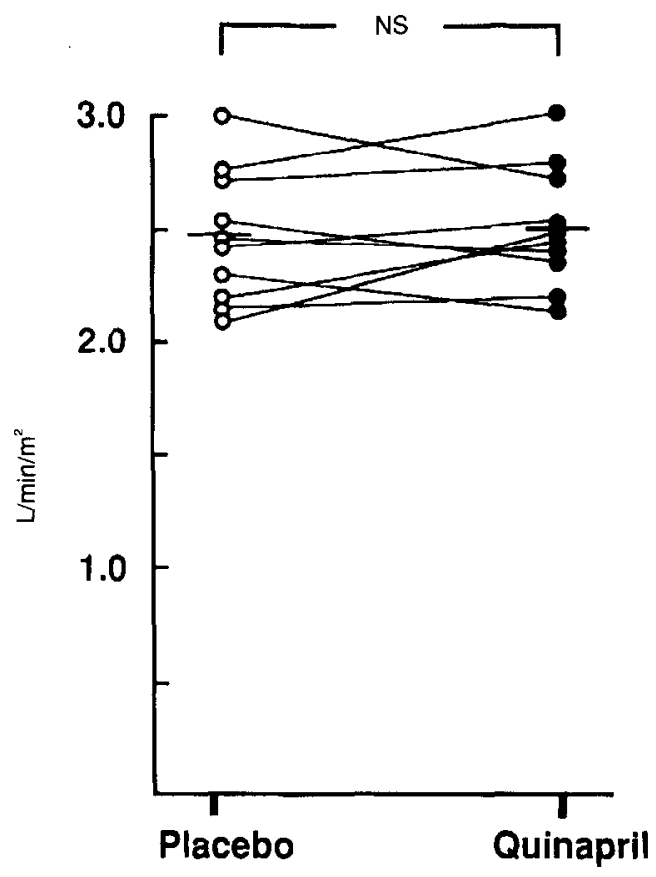

Fig. 2. Individual values for cardiac index with quinapril and placebo (NS).

for placebo and quinapril, respectively; $p<0.01$ ). Left ventricular wall stress decreased significantly with quinapril compared with placebo $(149 \pm 9$ versus $170 \pm 8 \times 10^{3}$ dynes $/ \mathrm{cm}^{2}, p<0.01$ ). Previously unanalyzed records of the Doppler sonography showed improvements in diastolic function: the peak $\mathrm{E} / \mathrm{A}$ ratio increased in 8 of the 10 patients, and the overall increase was significant (from $1.12 \pm 0.11$ to $1.31 \pm 0.10$ arbitrary units for placebo and quinapril, respectively; $p<0.02$ ).

Renal hemodynamics. Renal blood flow remained unchanged in the 10 patients $(907 \pm 36$ vs $896 \pm 28$ $\mathrm{ml} / \mathrm{min}$ for quinapril and placebo, respectively) (Fig. $3)$. However, renal vascular resistance was significantly $(p<0.05)$ lower when taking quinapril (12.2 \pm 0.8 arbitrary units) compared with placebo $(13.6 \pm 0.6)$, which suggests that reduced renal vascular resistance may partly explain the reduction in total vascular resistance during treatment with quinapril. Glomerular filtration rate and filtration fraction remained unchanged, which resulted in a lower glomerular filtration pressure.

\section{DISCUSSION}

ACE inhibition induces a decrease in total and renal vascular resistance without changing cardiac output. 9-11, 27-29 Quinapril lowers blood pressure by the same mechanism. The changes induced by quinapril differ from the reduced cardiac output and

\section{Renal Blood Flow}

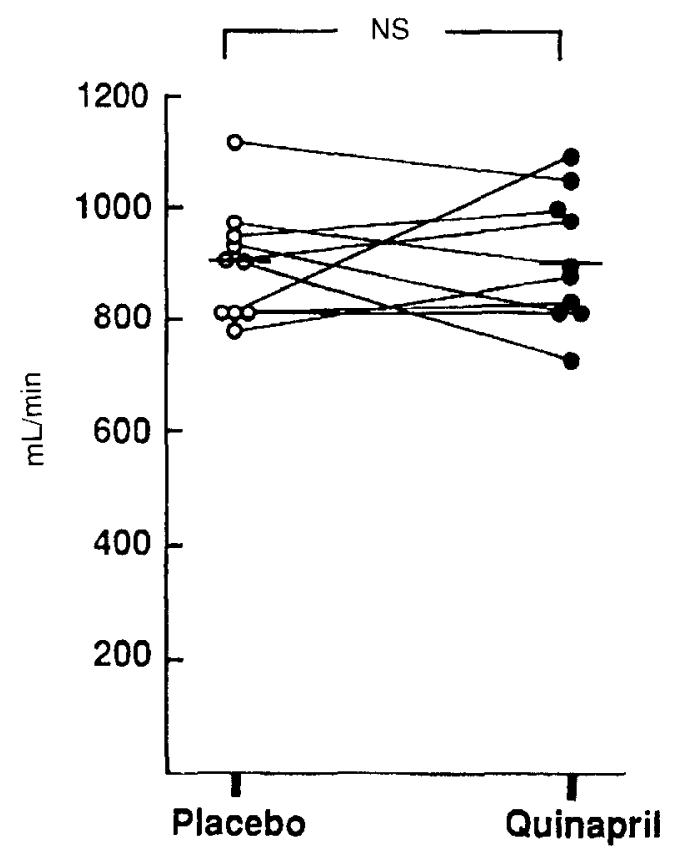

Fig. 3. Individual values for renal blood flow with quinapril and placebo (NS).

unchanged total peripheral resistance observed with $\beta$-blockade. ${ }^{1} \beta$-Blockade may worsen ${ }^{1}$ the already depressed cardiac function in hypertension. ${ }^{30-32}$ In contrast, vasodilation, as with an ACE inhibitor, may reverse the established vascular changes in hypertension and may be preferable for long-term treatment of hypertension.

The degree of counteracting reflex tachycardia and the increase in cardiac output vary widely with vasodilator therapy of hypertension. ${ }^{5-11}$ Even though quinapril produced a substantial fall in blood pressure, heart rate and plasma catecholamines remained virtually unchanged. The same observation has been made for captopril, ${ }^{9,10,27-29,33}$ enalapril, ${ }^{11,34}$ and lisinopril, ${ }^{34}$ and appears to be a class effect of ACE inhibition. It has been shown that with captopril, 35,36 enalapril, ${ }^{37,38}$ and lisinopril, ${ }^{38}$ the absence of reflex tachycardia with blood pressure reduction may be related to increased parasympathetic tone. It is likely that the absence of tachycardia with quinapril has a similar mechanism.

The reduction in systemic vascular resistance by long-term ACE inhibition appears to be unevenly distributed in the circulation. Lisinopril did not change the splanchnic vascular resistance, ${ }^{39}$ and we $\mathrm{e}^{21}$ did not detect a significant decrease in forearm vascular resistance with quinapril. However, captopril $^{28,29,40,41}$ and lisinopril ${ }^{39}$ and in the present study quinapril reduced renal vascular resistance. This 
may be explained by the particularly pronounced vasoconstricting action of angiotensin II in the renal circulation, ${ }^{42,43}$ especially in patients with essential hypertension. ${ }^{44}$

Long-term treatment of essential hypertension with captopril or enalapril has been associated with no change ${ }^{45,46}$ or a relatively small increase ${ }^{29,39,41}$ in renal blood flow and unchanged glomerular filtration rate. ${ }^{29,39-41,45,46}$ An increase in renal blood flow may possibly be related to withdrawal of the effect of angiotensin, which is more potent in constricting the efferent than the afferent glomerular arteriole. ${ }^{47}$ However, a fall in filtration fraction may also indicate a redistribution of renal blood flow to more superficial nephrons known to have a low filtration frac$\operatorname{tion}^{48,49}$ or relate to reduction in glomerular capillary hydraulic pressure ${ }^{50}$ In the present study, the fall in blood pressure and renal vascular resistance was not accompanied by a change in renal plasma flow, glomerular filtration rate, or filtration fraction. Presumably the failure of renal blood flow to increase was caused by a reduction in perfusion pressure. Thus the effect of quinapril on renal function is consistent with intact autoregulation of renal hemodynamics. This conclusion is in agreement with studies in laboratory animals, ${ }^{51}$ in which angiotensin II was not required for renal autoregulation.

We found left ventricular peak systolic wall stress in the same range as reported by others. ${ }^{52}$ Although we demonstrated a significant reduction in wall stress and, as estimated by the peak E/A ratio, an improvement in diastolic function, we did not find a significant reduction in left ventricular mass. ACE inhibition may decrease left ventricular mass. ${ }^{53}$ However, a 4-week treatment period may be too brief to detect such changes and longer studies will be required.

Oral administration of quinapril 12 hours after a previous dose produced no significant acute hemodynamic effects. This may seem somewhat surprising, because the plasma half-life of the active metabolite, quinaprilat, is approximately 2 hours and the effective accumulation is 3 hours after a single $20 \mathrm{mg}$ $\operatorname{dose}^{54}$ and quinaprilat is minimally detectable in plasma 8 to 12 hours after administration. ${ }^{54,55} \mathrm{How}$ ever, quinapril-induced plasma ACE inhibition is almost complete at 8 to 12 hours and is still depressed by $25 \%$ at 24 hours after administration, suggesting tight binding of the drug to the enzyme. ${ }^{55}$ In addition, quinaprilat ${ }^{55}$ has been demonstrated to inhibit tissue ACE even after plasma $A C E$ activity has returned to near-normal levels. Although the precise contribution of tissue angiotensin II production to hypertension is not yet defined, the antihypertensive effect of ACE inhibition more closely parallels tissue than plasma ACE inhibition during long-term administration in some models. ${ }^{56}$ The prolonged antihypertensive effect of quinapril in humans at a time when plasma drug concentration of quinaprilat is minimal may relate either to sustained plasma ACE inhibition or to effects mediated by the endogenous tissue renin-angiotensin system.

We thank the staff of the University of Michigan Clinical Research Center for technical assistance.

\section{REFERENCES}

1. Lund-Johansen P. Central haemodynamic effects of betablockers in hypertension. A comparison between atenolol, metoprolol, timolol, penbutolol, alprenolol, pindolol, and bumitrolol. Fur Heart . 1 1983;4(suppl D):1-12.

2. Kaiser P. Physical performance and muscle metabolism during beta-adrenergic blockade in man. Acta Physiol Scand 1984;122(suppl 536):1-53.

3. Gullestad L, Dolva LO, Kjeldsen SE, Eide I, Kjekshus J. The effects of naloxone and timolol on plasma catecholamine levels during short-term dynamic exercise. Scand J Clin Lab IIvest $1987 ; 47: 847-51$.

4. Gullestad L, Dolva LO, Kjeldsen SE, Eide I, Kjekshus J. Effect of beta-adrenergic blockade on hormonal responses during continuous and intermittent exercise. Cardiovasc Drugs Ther 1989;3:63-71.

5. Lund-Johansen P. Hemodynamic changes at rest and during exercise in long-term prazosin therapy for essential hypertension. Postgrad Med J 1975;58(suppl 1):45-52.

6. Lund-Johansen P, Omvik P, Haugland H. Acute and chronic haemodynamic effects of doxazosin in hypertension at rest and during exercise. Br J Clin Pharmacol 1986;21:45S-54.

7. Lund-Johansen P. Hemodynamic long-term effects of verapamil in essential hypertension at rest and during exercise Acta Med Scand 1984;215(suppl 681):109 15.

8. Lund-Johansen P, Omvik P. Haemodynamic effects of nifedipine in essential hypertension at rest and during exercise. J Hypertens 1983;1:159-63.

9. Tarazi RC, Bravo EL, Fouad FM, Omvik P, Cody RJ. Hemodynamic and volume changes associated with captopril. $\mathrm{Hy}$ pertension 1980;2:576-85.

10. Fagard R, Bulpitt C, Lijnen P, Amery A. Response of the systemic and pulmonary circulation to converting-enzyme inhibition (captopril) at rest and during exercise in hypertensive patients. Circulation 1982;65:33-9.

11. Lund-Johansen $P$, Omvik P. Long-term hemodynamic effects of enalapril at rest and during exercise in essential hypertension. Scand J Urol Nephrol 1984;18(suppl 79):87-91.

12. Gavras H, Brunner HR, Laragh JH, Sealey JF, Gavras I, Vucovich RA. An angiotensin converting enzyme inhibitor to identify and treat vasoconstrictor and volume factors in hypertensive patients. N Engl J Med 1974;291:817-21.

13. Fergusson H, Brunner HR, Turini CA, Gavras H. A specific orally active imhibitor of angiotensin converting enzyme in man. Lancet 1977;1:775-8.

14. McCaa RE, Hall JE, McCaa CS. The effects of angiotensin I-converting enzyme inhibitors on arterial blood pressure and urinary sodium excretion. Role of the renal renin-angiotensin and kallikrein-kinin systems. Circ Res 1978;43(suppl 1): $32-9$.

15. Moore TJ, Crantz FR, Hollenberg NK, et al. Contribution of prostaglandins to the antihypertensive action of captopril in essential hypertension. Hypertension 1981;3:168-73.

16. Cohen DM, Evans DB, Ryan MJ, Kaplan HR. Quinapril. In: Scriabine A, ed. New drugs annual: cardiovascular drugs. Vol 3. New York: Raven Press, 1985;71:84.

17. Sedman AJ, Posvar E. Clinical pharmacology of quinapril in healthy volunteers and in patients with hypertension and congestive heart failure. Angiology 1989;40(4, part 2):360-9. 
18. Maclean D. Quinapril: a double-blind, placebo-controlled trial in essential hypertension. Angiology 1989;40(4, part 2):370-81.

19. 'Taylor SH. The treatment of mild to moderate hypertension with ACE inhibitors. J Cardiovasc Pharmacol 1990;15(suppl 2):S24-8.

20. Knapp LE, Frank GJ, McLain R, Rieger MM, Posvar E, Singer $R$. The safety and tolerability of quinapril. J Cardiovasc Pharmacol 1990;15(suppl 2):S47-55.

21. Gupta RK, Kjeldsen SE, Krause L, Kneisley J, Posvar E, Weder AB, Julius S. Hemodynamic effects of quinapril, a novel angiotensin-converting enzyme inhibitor. Clin Pharmacol Ther 1990;48:41-9.

22. Hinderliter AL, Fitzpatrick MA, Schork N, Julius S. Research utility of non-invasive methods for measurement of cardiac output. Clin Pharmacol Ther 1987;41:419-25.

23. Julius S, Jamerson K, Mejia A, Krause L, Schork N, Jones K. The association of borderline hypertension with target organ changes and higher coronary risk: Tecumseh Blood Pressure Study. JAMA 1990;264:354-8.

24. Rydstedt LL, Williams GH, Hollenberg NK. Renal and endocrine response to saline infusion in essential hypertension. Hypertension 1986;8:217-22.

25. Schnurr E, Lahme W, Kuppers H. Measurement of renal clearance of insulin and PAH in the steady state without urine collection. Clin Nephrol 1980;13:26-9.

26. Peuler JD, Johnson GA. Simultaneous single isotope radioenzymatic assay of plasma norepinephrine, epinephrine and dopamine. Life Sci 1977;21:625-36.

27. Muiesan G, Alicandri CL, Agabiti-Rosei E, et al. Angiotensinconverting enzyme inhibition, catecholamines and hemodynamics in essential hypertension. Am J Cardiol 1982;49: 1420-4.

28. Ando K, Fujita T, Ito Y, Noda H, Yamashita K. The role of renal hemodynamics in the antihypertensive effect of captopril. AM HEART J 1986;111:347-52.

29. Dupont AG, Vanderiepen P, Bossuyt AM, Jonckheer MH, Six RO. Effect of enalapril on ambulatory blood pressure, renal hemodynamics and cardiac function in essential hypertension. Acta Cardiol (Brux) 1986;41:353-8

30. Brod J, Fencl V, Hejl 7, Jirka .J, Jlrych M. General and regional hemodynamic pattern underlying essential hypertension. Clin Sci 1962;23:339-49.

31. Lund-Johansen P. Haemodynamics in early essential hypertension. Acta Med Scand 1967;181(suppl 482):1-101.

32. Lund-Johansen P. Central hemodynamics in essential hypertension at rest and during exercise: a 20-year follow-up study [Abstract 511]. Presented at the Fourth European Meeting on Hypertension, Milan, Italy, June 21-22, 1989.

33. Campluell BC, Shepherd AN, Reid JL. Effects of the angiotensin converting enzyme inhibitor, captopril, in essential hypertension. Br J Clin Pharmacol 1982;13:213-7.

34. Millar JA, Derkx FM, McLean K, Reid JL. Pharmacodynamics of converting enzyme inhibition: the cardiovascular, endocrine and autonomic effects of MK421 and MK521. Br J Clin Pharmacol 1982;14:347-55.

35. Sturani A, Chiarini C, Degli Esposti E, Santoro A, Zuccala A, Zuchelli $P$. Heart rate control in hypertensive patients treated by captopril. Br J Clin Pharmacol 1982;14:849-55.

36. Campbell BC, Sturani A, Reid JL. Evidence of parasympathetic activity of the angiotensin converting enzyme inhibitor, captopril, in normotensive man. Clin Sci 1985;68:49-56.

37. Ibsen H, Egan B, Osterziel K, Vander A, Julius S. Reflex-hemodynamic adjustments and baroreflex sensitivity during converting enzyme inhibition with MK-421 in normal humans. Hypertension 1983;5(suppl):I-184-I-191.

38. Ajayi AA, Campbell BC, Howie CA, Reid JL. Acute and chronic effects of the converting enzyme inhibitor enalapril and lisinopril on reflex control of heart rate in normotensive man. J Hypertens 1985;3:47-53.

39. Garavaglia GE, Messerli FH, Nunez BD, Schmieder RE, Frohlich ED. Immediate and short-term cardiovascular effects of a new converting enzyme inhibitor (lisinopril) in essential hypertension. Am J Cardiol 1988;62:912-6.

40. Brunner HR, Gavras H, Waeber B, Textor SD, Turini GA, Wauters JP. Clinical use of an orally active converting enzyme inhibitor: captopril. Hypertension 1980;2:558-66.

41. Kiowski W, van Brummelen P, Hulthen L, Amman FW, Buhler FR. Antihypertensive and renal effects of captopril in relation to renin activity and bradykinin-induced vasodilation. Clin Pharmacol Ther 1982;31:677-84.

42. Hollenberg $N$. Renal response to angiotensin-converting enzyme inhibition. Am J Cardiol 1982;49:1425-9.

43. Navar L, Rosivall L. Contribution of the renin-angiotensin system to the control of intrarenal hemodynamics. Kidney Int 1984;25:857-68.

44. Hollenberg NK, Meggs LG, Williams GH, Katz J, Garnic JD, Harrington DP. Sodium intake and renal responses to captopril in normal humans and essential hypertension. Kidney Int 1981;20:240-5.

45. Pessina AC, Semplicini A, Rossi G, et al. Effects of captopril on renal function in hypertensive patients. Am $\mathrm{J}$ Cardiol 1982;49:1572-3.

46. Duchin KL, Willard DA. The effect of captopril on renal hemodynamics in hypertensive patients. J Clin Pharmacol 1984; 24:351-9.

47. Ljungman S, Aurell M, Hartford M, Wikstrand J, Berglund G. Effects of subpressor doses of angiotensin II on renal hemodynamics in relation to blood pressure. Hypertension 1983;5:368 74 .

48. Navis GJ, DeJong PE, Donker AJM, DeZeeuw D. Effects of enalapril on blood pressure and renal hemodynamics in essential hypertension. Proc EDTA 1983;20:577-81.

49. Baur JH, Reams G, Gaddy P. Renal function and hemodynamics during treatment with enalapril in primary hypertension. Nephron 1986;44(suppl 1):83-6.

50. Hall JE, Guyton AC, Jackson TE, Coleman TG, Lohmeier TE, Trippodo NC. Control of glomerular filtration rate by reninangiotensin system. Am J Physiol 1977;233:F366-72.

51. Murray RD, Malvin RL. Intrarenal renin and autoregulation of renal plasma flow and glomerular filtration rate. Am J Physiol 1979;236:F559-6.

52. Hartford M, Wikstrand JCM, Wallentin I, Ljungman SMG, Berglund GL. Left ventricular wall stress and systolic function in untreated primary hypertension. Hypertension 1985;7:97104

53. Fouad FM, Tarazi RC. Restoration of cardiac function and structure by converting enzyme inhibition: possibilities and limitations of long-term treatment in hypertension and heart failure. J Cardiovasc Pharmacol 1986;8(suppl 1):S53-7.

54. Olson SC, Horvath AM, Michniewicz BM, Sedman AJ, Colburn AJ, Welling PG. The clinical pharmacokinetics of quinapril. Angiology 1989;40(4 part 2):351-9.

55. Johnston CI, Mendelsohn FAO, Cubela RB, Jackson B, Kohzuki M, Fabris B. Inhibition of angiotensin converting enzyme (ACE) in plasma and tissues: studies ex vivo after administration of ACE inhibitors. J Hypertens 1988;6(suppl 3):S17-S22.

56. Unger T, Ganten D, Lang RE, Scholkens BA. Is tissue converting enzyme inhibition a determinant of the antihypertensive efficacy of converting enzyme inhibitors? Studies with the two different compounds, Hoe 498 and MK 421, in spontaneously hypertensive rats. J Cardiovasc Pharmacol 1984; 6:872-80. 